\title{
Preschool children's prejudices: A phenomenological study
}

\section{Okul öncesi dönem çocuklarının ön yargıları: Fenomenolojik bir çalışma}

\section{Article History \\ Received : 19 February 2019 \\ Revised : 04 March 2019 \\ Accepted : 09 March 2019 \\ Online : 10 March 2019}

\section{Article Type}

Research Article

\author{
Meryem Nur Çelik ${ }^{1}$, İkbal Tuba Şahin-Sak ${ }^{2}$
}

\begin{abstract}
Data for this phenomenological study of preschoolers' prejudices were collected through an interview protocol developed by the researchers. The participants, selected using purposeful sampling, were 100 four- to six-year-old children from Van, Turkey. For data analysis, coders looked firstly at word or phrase repetition, and then at the connectors the children used. This revealed that the children had several distinct prejudices related to each of seven main themes drawn from the existing literature: (1) race, (2) age, (3) physical abilities, (4) physical characteristics, (5) economic class, (6) gender and (7) family composition. However, some of the children's prejudices were nested and interrelated. For instance, when expressing prejudices related to age, they tended to exhibit their prejudices related to gender or physical characteristics.
\end{abstract}

Keywords: Prejudice, Preschool period, Young children, Phenomenology

Öz: Okul öncesi dönem çocuklarının ön yargılarını belirlemek amacıyla yapılmış olan bu fenomenolojik çalısmanın verisi, araştırmacıların geliştirmiş oldukları bir görüşme formu ile toplanmıştır. Çalışmanın katılımcılarını, amaçlı örnekleme yöntemi ile seçilen ve Van'da yaşayan, dört-altı yaş grubu 100 çocuk oluşturmaktadır. Çalışmada nitel veri analizi için iki teknik kullanılmıştır. İlkinde katılımcılar tarafından tekrar edilen kelime ve ifadeler belirlenmiş, diğerinde ise katılımcıların kullandıkları bağlaçlar incelenmiştir. Veri analizi sonunda, literatüre ve bu çalışmada temel alınan ön yargılara paralel olarak yedi ana tema belirlenmiştir: (1) 1rk, (2) yaş, (3) fiziksel yeterlilikler, (4) fiziksel özellikler, (5) ekonomik durum, (6) cinsiyet ve (7) aile yapısı. Çalışmanın bulguları, çocukların her bir temaya ilişkin farklı ön yargıları olduğunu göstermektedir. Bununla birlikte, bazı durumlarda bu ön yargılar iç içe geçmiş durumdadır. Örneğin çocuklar yaş ile ilgili durumları açıklarken cinsiyet veya fiziksel özelliklerle ilgili ön yargilarını da ortaya koyabilmektedir.

Anahtar kelimeler: Ön yarg1, Okul öncesi dönem, Çocuklar, Fenomenoloji

DOI: $10.24130 /$ eccd-jecs. 1967201931132

Corresponding Author: İkbal Tuba Şahin-Sak

${ }^{1}$ Ministry of National Education, meryemnurcelik@gmail.com, ORCID: https://orcid.org/0000-0002-3760-7733

2 Van Yüzüncü Y1l University, School of Education, Early Childhood Education, ikbalsahin@gmail.com, ORCID: https://orcid.org/0000-00029054-6212

This article was extracted from the first author's master's thesis.

\footnotetext{
Atıf için/To cite this article:

Çelik, M., \& Şahin-Sak, İ. (2019). Preschool children's prejudices: A phenomenological study. Erken Çocukluk Çalşsmalar Dergisi, 3(1), 55-75. doi:http://dx.doi.org/10.24130/eccd-jecs.1967201931132
} 


\section{INTRODUCTION}

Prejudice consists of perceptions of a person or group that have been learnt and settled in a pattern (Çetin, 2012). The number and intensity of prejudices varies across individuals (Pettigrew, 1958), and some prejudices involve a belief that all individuals in a given group have same characteristics (Morgan, 2013; see also Zick et al., 2008). In addition to classifying people, other key characteristics of prejudice are the emergence of stereotypical judgments, distancing of people from one another, and feelings of inferiority on the people they are prejudiced against (Çetin, 2012). Prejudices commonly relate to race, age, physical abilities, physical characteristics, economic class, gender and family composition (Arslan \& Kutsal, 2001; Doyle \& Aboud, 1995; Wolpert, 2002). Young children are especially likely to hold prejudiced views of old people as physically weak (Wolpert, 2002), though other physical characteristics of one's interlocutor such as weight, height, hair color and eye color have also have been found to influence decision-making processes (Karagöz, 2014; Sigelman et al., 1986). Media are especially important in the development of some prejudices related to economic class, because media images tend to valorize money and associate it with importance and power (Wolpert, 2002).

Ekmişoğlu's research (2007) on the early development of prejudices found that children start to recognize differences at one year old. At age two, they start to talk about the differences between people and ask questions about them. By age three, they start to form prejudices and to reveal features of other people that make them uncomfortable. At four, they think about people's differences in detail, and start to form concepts based on these differences. At five, they are aware of their own characteristics and try to learn which of them are temporary vs. permanent. At six, they start to develop a better understanding of the reasons for human differences, and to accept that they are unchangeable. And lastly, at seven and eight, they start to recognize their own culture clearly, and develop self-esteem related to it. Because children start to recognize the different characteristics of people so early, Turkey's preschool program includes some specific objectives related to respect for diversity. For instance, "the child respects diversity" or "the child recognizes different cultural characteristics" (Ministry of National Education-MoNE, 2013).

Williams and O'Reilly (1998, p. 81) defined diversity as "any attribute that another person may use to detect individual differences", which might include their races, classes, religions, learning styles, communication styles, jobs, and even birthplaces (Sonnenschein, 1997; see also Jackson, Joshi, \& Erhardt, 2003). For children, diversity implies confronting an array of unfamiliar objects and events. As such, to reach preschools' diversity-related objectives, it is important to determine what children see as different and what their prejudices are. Nevertheless, research on children's 
prejudices is sparse, and the few studies that have been conducted have tended to focus on only one characteristic, often gender or race (Akbalık, 1998; Akın, 2007; Aydilek Çiftçi \& Özgün, 2011; Aytaç, 2013; Bağçeli Kahraman \& Başal, 2011; Ersoy, 2009; İnci Kuzu, 2015; Kowalski, 2003; Kustatscher, 2017; Penny, 2007; Pica, 2008; Sak et al., 2015; Thorman, 2002; Ünlü, 2012; Williams, 2012; Yağan Güder \& Güler Yıldız, 2016; Zargarpour, 2001). The current study therefore examines children's relationships to all seven of the main types of prejudice identified in the adult realm by Wolpert (2002), not merely to fill the gaps in the existing literature, but to help parents, preschool teachers and curriculum developers who wish to identify and deal with children's prejudices in realworld situations. It will be guided by the following seven research questions:

1. What racial prejudices, if any, do Turkish preschool children have?

2. What age-related prejudices, if any, do they have?

3. What, if any, are their prejudices related to physical abilities?

4. What, if any, are their prejudices related to physical characteristics?

5. What class prejudices, if any, do they have?

6. What gender prejudices, if any, do they have?

7. What, if any, are their prejudices related to family composition?

\section{METHOD}

\section{Research Design}

Phenomenological research focuses on how an individual understands himself and his environment; and this process of understanding cannot be separated from his assumptions and prejudices, which should therefore also be examined and interpreted (Robson, 2015). This study aims to examine prejudices of young children. A phenomenological approach was selected for this research, due to its focus on explaining how young children understand themselves and their environment through their prejudices.

\section{Participants}

Purposeful sampling enables the researcher to choose participants who are more likely than others to provide data relevant to the studied phenomenon (Merriam, 2009). This study purposefully sampled preschoolers from a range of different socio-economic status (SES) backgrounds, but all living in the same Turkish region. Of the 100 participants (46 female, 54 male), 38 attended public schools, and the other 62, private schools. All were aged between 48 and 72 months. 
Slightly more than half $(n=53)$ had no prior experience of preschool. Of the others, 24 had attended during one previous year, 21 during two previous years, and two, during three years. Just under a third $(n=32)$ did not have any siblings; of the remainder, none had more than five siblings. Half the participants were firstborns $(n=50)$, with second children making up the second largest group $(n=31)$. The mother tongue of most of the children $(n=84)$ was Turkish; for the remainder, it was Kurdish.

The great majority of the children $(n=95)$ lived in urban districts of the city of Van, with just five living in its rural hinterland. More than half of the participants' parents had monthly incomes of more than 2,000 Turkish lira $(n=56)$, with most of the rest falling into the range of $1,001-1,500$ $(n=22)$. However, five of the children's household incomes were less than 500 lira. Their family compositions fell into four categories: nuclear $(n=71)$, extended $(n=21)$, divorced but extended $(n=2)$, and single parent $(n=6)$. Eight of the children had an overweight relative or neighbor, and 13 a disabled one. Only one child had a male preschool teacher.

\section{Data Collection Tool}

Data was collected through a pictorial tool developed by the researchers, called the Interview Protocol for Prejudices of Preschool Children. Its development began with a comprehensive review of the literature related to prejudices, children's prejudices and prejudices in education, which yielded the seven main themes listed in the Introduction, above (see also Derman-Sparks \& Edwards, 2010; Wolpert, 2002). Then, researchers brainstormed pictures and questions for each theme and wrote down the results. These notes were shared with an experienced preschool teacher and two academic specialists in preschool education and qualitative research. Based on these experts' suggestions, some of the initial ideas were eliminated and the wording of some questions simplified slightly.

Next, a draft interview protocol and a demographic information form were prepared and sent to five experts: the teacher, the same two academics mentioned above, and two additional. Based on their opinions, more changes - relating especially to the pictures - were made. With regard to the demographic information form, they recommended the addition of some questions focusing on the SES and composition of the participants' families and the gender of their teachers.

Then, a pilot study was conducted with three children, with a special focus on the intelligibility of the protocol's pictures and questions. Since two of three children did not understand the Turkish word for interesting (ilginç), it was changed to a word meaning different (değişik/farklı). The pilot 
study also led to each picture being given a black frame to more clearly differentiate it from the others.

The final protocol consisted of two parts. The first contained the demographic items, and the second, 12 color pictures (printed on glossy photographic paper) and 31 questions aimed at determining their prejudices related to race, gender, physical ability, physical characteristics, economic class, gender and family composition.

\section{Data Collection Procedure}

First, permission to conduct the study was sought and obtained from Turkey's National Education Directorate. Then, parents were contacted through school administrators and teachers, and informed of the study's aims. After the parents had signed consent forms, one of the researchers spent time observing each of the children, on days decided in consultation with their respective classroom teachers. On the same occasions, the teachers introduced her to the children to familiarize them with her. Then, each interview was conducted one-on-one in places within each school that were deemed appropriate by that school's staff. To save time and ensure the completeness of their data, the researchers asked the parents for permission to audio-record the interviews. Such permission was withheld in the case of 15 children, whose interview responses were therefore recorded by hand. The duration of the interviews ranged between 20 and 40 minutes.

\section{Data Analysis}

All interviews recordings and notes were transcribed onto computer files. Then, all the transcripts were read several times and coded by two researchers separately. For data analysis, coders looked firstly for word or phrase repetition, and secondly at the connectors the children used (Bernard \& Ryan, 2010). In terms of word repetition, for instance, it was noted that the participants focused especially on the skin color of the children in one picture. Connectors were examined because they indicate children's views on cause-and-effect relationships, if-conditions, and some relations based on time (Bernard \& Ryan, 2010). For instance, when one child said "driving a car is hard. Therefore, drivers should be men", the connecting word clarified why he preferred male drivers.

After the two coders had completed their respective codes, they came together to determine the data's main themes, and reached 93\% agreement on their codes. After referring to literature with regard to the $7 \%$ of codes that were in dispute, they still could not come to an agreement on $3 \%$ 
of them, which were therefore dropped from analysis. At the end of analysis, the seven main themes discussed above (e.g., Wolpert, 2002) were unchanged.

\section{Trustworthiness}

One strategy for ensuring the validity of qualitative research is prolonged engagement (Creswell \& Miller, 2000). This was the main reason that one of the researchers spent time with the participants in their classrooms before the interviews were conducted. In terms of qualitative studies' reliability, inter-coder agreement (as described in detail in the previous section) is considered critically important (Creswell, 2007).

\section{FINDINGS}

\section{Race}

When the participants were asked what they saw in a picture of black and white children playing, nearly all of them ( $n=96)$ stated that there were children playing with toys. However, they had varying views on the differences between children. More than two-fifths of the participants $(n=43)$ mentioned that some of the pictured children were white and some black, and 11 of these also stressed the gender of the children. One said:

These are bad children. I saw them near my grandfather's home. $\left(\mathrm{C}_{91}\right.$, boy)

Ten participants stated that there were not any differences between the children; three emphasized their genders but not their races. Approximately one in three $(n=31)$ participants stated that they would prefer playing with a white girl, for reasons including:

Black children are different. $\left(\mathrm{C}_{47}, \mathrm{C}_{52}\right.$, girls)

When we play with boys, we become a boy. $\left(\mathrm{C}_{15}\right.$, girl)

She is beautiful. $\left(\mathrm{C}_{37}, \mathrm{C}_{62}, \mathrm{C}_{71}\right.$, girls $)$

Of the 54 male participants, 24 emphasized that they would want to play with white boys, but of these 24 , only four $-\mathrm{C}_{83}, \mathrm{C}_{85}, \mathrm{C}_{91}$ and $\mathrm{C}_{98}$ - stated that this was due to their similarity of skin color.

Some $(n=19)$ of the participants who did not mention the gender of children claimed that they would play with white children. Their comments included: 
I don't like black people. ( $\mathrm{C}_{32}$, boy)

I like whites more. $\left(\mathrm{C}_{33}\right.$, girl $)$

White people are more beautiful. $\left(\mathrm{C}_{84}, \mathrm{C}_{93}\right.$, boys)

Five participants stated that they would prefer playing with black children only: $C_{7}$ (boy) because he did not have any black friends and $\mathrm{C}_{97}$ (boy) because they were different and being different was good. Two participants said that they would play with none of the pictured children: $\mathrm{C}_{80}$ (girl) because they were strangers and $\mathrm{C}_{98}$ (boy) because they were all older than him. Lastly, 13 participants said that they would play with all the children in the picture because all of them were friends.

Slightly over a third of the participants $(n=37)$ stated that they looked like the pictured white boy, while 36 claimed to resemble the girl with blonde hair. Five participants thought that they looked like black children, and two others that they looked like no-one in the picture. Five children emphasized only that they were white.

More than half the participants $(n=55)$ stated that they did not want to look like the black children in the picture, and used some negative terms to explain this preference, calling black children ugly, funny, horrible, naughty and bad while some claimed they were not smart and normal like participant children. Some said:

I don't like black children. $\left(\mathrm{C}_{10}, \mathrm{C}_{27}, \mathrm{C}_{71}\right.$, girls; $\mathrm{C}_{2}, \mathrm{C}_{45}, \mathrm{C}_{66}$, boys $)$

If I were black, everybody would langh at me. ( $\mathrm{C}_{19}$, girl; $\mathrm{C}_{82}$, boy)

If I were black, it would be hard to bide when playing. $\left(\mathrm{C}_{100}\right.$, girl $)$

All 11 participants who stated that they would want to look like white children justified this preference based on esthetics. Nine cited beauty/ugliness, and the other two said that white children usually became thin whereas blacks were usually fat.

Six participants stated that they wanted to look like all the children in the picture, and five that they wanted to look like the black ones. Of the latter group, two said:

I would be different. ( $\mathrm{C}_{23}$, girl) 
I want to bave black and curly bair like them. $\left(\mathrm{C}_{8}\right.$, boy)

Lastly, $\mathrm{C}_{13}$ (girl) said "I don't want to look like white children", and added, "[b]ecause all people are different from each other. Nobody has to look like another person. Being different is good."

\section{Age}

For this dimension, the participants were shown two pictures, one of an elderly woman riding a bike, and the other of a similar woman knitting and sitting with some children who might have been her grandchildren. Most $(n=89)$ said of the bike-rider that they saw a grandmother or old lady, though six described her simply as a woman, and five others as a mother. Of the second picture, two-fifths ( $\mathrm{n}=40$ ) saw a grandmother or a woman engaged in hand-work such as knitting or sewing. A smaller, but still large proportion of the participants $(n=30)$ mentioned the presence of the children in the picture, but not the hand-work.

Nearly two-thirds of the participants $(n=64)$ emphasized that a grandmother riding a bike was different or interesting, and an additional 27 that an old lady or a mother riding a bike was interesting. Some of them focused on the age of the woman, saying:

I have never seen an old lady riding a bike. $\left(\mathrm{C}_{40}\right.$, boy)

Grandmothers can't walk without a walking stick. ( $\mathrm{C}_{64}$, boy)

In all, 38 participants rejected the notion that a grandmother could ride a bike, with 18 citing nonage-specific reasons such leg pain $\left(\mathrm{C}_{88}, \mathrm{C}_{94}\right.$, boys), and the other 20 stating that grandmothers were too old. Most participants $(n=85)$ said they preferred their grandmothers to knit, 18 specifying that this preference was because bike-riding by grandmothers or old people was impossible; eight said they would prefer their grandmothers to ride than knit, and only three that they would like them to do both. Two boys $\left(\mathrm{C}_{18}, \mathrm{C}_{51}\right)$ and two girls $\left(\mathrm{C}_{29}, \mathrm{C}_{73}\right)$ stated that no women could ride bikes. Only three participants said there was nothing different or interesting about an old lady riding a bike.

\section{Physical Abilities}

Two pictures related to physical abilities were shown to children: the first of a disabled woman in a wheelchair reading a book to some children; and the other of three children with one leg, flying kites. With regard to the first picture, the participants identified it as showing a teacher and children $(n=29)$, a mother with girls and boys $(n=22)$, children $(n=11)$, a woman and children $(n=11)$, a 
mother/a teacher with broken leg $(n=10)$, a teacher $(n=7)$, children and someone in a wheelchair, $(n=5)$ or a woman $(n=5)$. Some participants who emphasized that the woman was a teacher $\left(C_{14}\right.$, girl; $\mathrm{C}_{74}, \mathrm{C}_{96}$, boys) said that this was because she was reading a book and showing pictures to children. Three others $\left(\mathrm{C}_{33}, \mathrm{C}_{34}\right.$, girls; $\mathrm{C}_{31}$, boy) commented that they would never see a teacher like her in real life because she was unable to walk.

Approximately half of participant children $(n=49)$ stated that there was nothing different or interesting case in the first picture, and the other half $(n=51)$ that woman in the wheelchair was different. $\mathrm{C}_{99}$ (girl) and $\mathrm{C}_{91}$ (boy) both commented that the woman was probably a visitor, because she was unable to play with children and therefore could not be a teacher.

More than half the participants $(n=56)$ said that they would want someone in a wheelchair to come and to read a book to them, because they liked fairytales and stories $(n=7)$, or liked visitors $(n=4)$, or wanted to meet someone who used a wheelchair $(n=2)$. Of these 56 , however, two $\left(C_{99}\right.$, girl; $C_{42}$, boy) thought she would be unable to come to class. Three girls and four boys $\left(\mathrm{C}_{5}, \mathrm{C}_{34}, \mathrm{C}_{62}\right.$, girls; $\mathrm{C}_{20}, \mathrm{C}_{32}, \mathrm{C}_{88}, \mathrm{C}_{92}$, boys) said they would help the woman, or wanted to help her. Two participants ( $\mathrm{C}_{100}$, girl; $\mathrm{C}_{98}$, boy) said "I could be like her."

A substantial minority of the participants $(n=40)$, however, stated that they would not want someone in a wheelchair to come to school, usually focusing on what such a person could not do. Of this group, four said that even she wanted to, she could not come $\left(\mathrm{C}_{17}, \mathrm{C}_{18}, \mathrm{C}_{35}, \mathrm{C}_{57}\right.$, boys); five said that she could not play with them $\left(\mathrm{C}_{89}\right.$, girl; $\mathrm{C}_{31}, \mathrm{C}_{46}, \mathrm{C}_{69}, \mathrm{C}_{85}$, boys); one, that she could not use stairs $\left(\mathrm{C}_{78}\right.$, girl); and one that she would not be able to drink a glass of water ( $\mathrm{C}_{81}$, boy). Other comments included:

Wheelchair seems bad. ( $\mathrm{C}_{52}$, girl; $\mathrm{C}_{40}$, boy)

She is disabled and she can infect us with her disease. $\left(\mathrm{C}_{58}\right.$, girl $)$

We can crash her in the classroom. ( $\mathrm{C}_{66}$, boy)

She will get upset when she sees that we can walk. ( $\mathrm{C}_{91}, \mathrm{C}_{93}$, boys)

Regarding the second picture, the majority of the participants $(n=59)$ mentioned that it showed children flying a kite. Among the participants who mentioned the children, 14 stated in general terms that one was disabled, and another seven specified that he used a crutch because his leg was broken. 
According to 47 participants, there was nothing different or interesting in the picture, but the other 53 stated that the child without a leg was different. Some of their comments included:

They are good boys but the child with the red shirt is disabled. ( $\mathrm{C}_{33}$, girl)

I think there is a problem related to the child with the red shirt. He may not have an arm or a leg. $\left(\mathrm{C}_{60}\right.$, boy)

The child with the red shirt has to use a crutch to walk. $\left(\mathrm{C}_{73}\right.$, girl; $\mathrm{C}_{70}$, boy $)$

More than two-fifths of the participants $(n=41)$ expressed a preference for playing with the nondisabled children in the picture, citing various reasons including the kite; friendships they imagined as existing within the depicted group; and the presumed ages of the children ("older people are ridiculous": $\mathrm{C}_{15}$, girl). However, six girls and four boys cited the disability specifically:

The disabled boy can't play with me. $\left(\mathrm{C}_{33}\right.$, girl $)$

The disabled child might infect me. $\left(\mathrm{C}_{58}\right.$, girl $)$

He is not disabled so looks nice. ( $\mathrm{C}_{76}, \mathrm{C}_{89}, \mathrm{C}_{90}$, girls)

He is not disabled and can play with me. ( $\mathrm{C}_{99}$, girl)

Other children can play but the disabled one can't. ( $\mathrm{C}_{48}, \mathrm{C}_{53}$, boys)

He doesn't have a leg and a shoe. ( $\mathrm{C}_{79}$, boy)

He can't run. ( $\mathrm{C}_{91}$, boy)

Eight other participants stated that they would like to play with one of the non-disabled children because of the kindness he was showing to the disabled one:

He helps his friend so I would like him. $\left(\mathrm{C}_{6}, \mathrm{C}_{52}\right.$, girl $)$

He helps the disabled child and helping is a good behavior. ( $\mathrm{C}_{95}$, girl; $\mathrm{C}_{7}, \mathrm{C}_{8}, \mathrm{C}_{35}, \mathrm{C}_{40}$, boys)

He is a good boy and gave his kite to the disabled child. $\left(\mathrm{C}_{10}\right.$, girl $)$

An additional 14 participants said that they would prefer to play with the disabled child because they would take him to the hospital $\left(\mathrm{C}_{4}, \mathrm{C}_{68}, \mathrm{C}_{96}\right.$, boys $)$ or help him in some less specific way $\left(\mathrm{C}_{20}\right.$, 
$\mathrm{C}_{32}, \mathrm{C}_{59}, \mathrm{C}_{92}, \mathrm{C}_{98}$, boys). Ten participants stated that they would play with all the children in the picture, in one instance because they were all boys $\left(\mathrm{C}_{64}\right.$, boy). Lastly, two children said they would not want to play with any of the depicted children because all of them were boys and they had their own friends.

\section{Physical Characteristics}

The participants were shown a picture of two thin and two fat children playing with balls, and asked what they saw. Most $(\mathrm{n}=69)$ said only that there were children playing with balls, while some stated that there were two fat and two thin children $(n=13)$, a fat child with a big stomach $(n=6)$, or two girls and two boys $(\mathrm{n}=6)$.

Most participants children usually emphasized that they would prefer to play with the thin children, but their reasons for this varied, including esthetics $(n=11)$, that fat people could not play properly or well $(n=8)$, that thin people would play better $(n=13)$, or that they themselves were thin so played with other thin children $(n=4)$. Two others said:

Fat children don't give the ball to me. I had a fat friend and he hit me. (C $\mathrm{C}_{82}$, boy)

Girls don't play with boys. (C40, boy)

Two participant children ( $\mathrm{C}_{46}, \mathrm{C}_{57}$, boys) said they would prefer to play with fat children, because they were sweaty. Six participants said that they would play with the fat girl, for reasons including her nice dress $\left(\mathrm{C}_{19}\right.$, girl $)$ and that nobody else would play with her because she was fat $\left(\mathrm{C}_{6}\right.$, girl $)$. Five children said they would prefer to play with the fat boy, two stating that this was because he was strong $\left(\mathrm{C}_{35}, \mathrm{C}_{81}\right.$, boys). Only one in six participants $(\mathrm{n}=17)$ said they would like to play with all the children in the picture.

\section{Economic Class}

There were two children in the picture related to economic class: one with new blue overalls and new toys, and the other with an old red shirt and broken toys. When asked what they saw on the picture, the participants mentioned one clean and one dirty child $(n=36)$; two boys $(n=28)$; and two children playing $(\mathrm{n}=13)$. One said:

The child with blue overalls did not give his good toys to the other child so he is sad. ( $\mathrm{C}_{80}$, girl) 
Some participants thought the child with the broken toys had fallen and was injured $(n=5)$ or was a bad child ( $\mathrm{n}=7)$. Of the seven who described him as bad, two thought the image was meant to depict a good child and a bad one $(n=2)$.

Nearly one in three participants $(n=30)$ said that there were no differences between the two children on the picture, or that they were similar. An equal number of others $(n=30)$ focused on the contrast in the two boys' clothing. Nearly as many $(n=27)$ emphasized that the child with the red shirt looked poor, and $\mathrm{C}_{91}$ (boy) specifically linked this to his old clothing. Of seven participants who mentioned the difference between the depicted children's shoes, one $\left(\mathrm{C}_{84}\right.$, boy) emphasized that because of the red-shirted boy's broken shoe, everybody would stare at him on the street. Though only a few participants $(n=6)$ said that the difference between the two children was that one was dirty, most $(n=79)$ stated that they would prefer to play with the child with the blue overalls, often focusing on his cleanliness as well as the condition of his toys. $\mathrm{C}_{79}$ (boy) stated that the dirtiness of the red-shirted boy's toys would make him ill if they played together, and $\mathrm{C}_{58}$ (girl) expressed a concern that he would break her toys.

Eight participants said they wanted to play with the child in the red shirt to help him in some way. For instance, $C_{3}$ (girl) said she would play with him because he was alone and his toys were old. $\mathrm{C}_{16}$ (girl) said she would play with him because the other child was rich and would not play with her. Seven participants said they would play with both children, and six with neither.

\section{Gender}

This dimension contained two pictures, one featuring a male preschool teacher and the other, a female school-bus driver. Nearly half the participants $(n=44)$ correctly identified the first as being of a teacher and children. However, nearly as many $(\mathrm{n}=39)$ claimed that the man in the picture was the father of one or more of the depicted children. Eight others thought that he was an adult older brother or an uncle, and seven failed to recognize any adult in the picture.

More of the participants $(n=56)$ found the presence of a male adult in picture of a preschool classroom than did not $(\mathrm{n}=44)$. One of the former group $\left(\mathrm{C}_{80}\right.$, girl $)$ said:

I think a male teacher is interesting in the classroom because my teacher is female. Also her hair is long. Men can't play with children.

Just over half the participants $(n=52)$ expressed a preference for a female teacher. Of these, some emphasized disciplinary practices, e.g., that when they were not quiet, a male teacher would get 
angry and hit them $\left(\mathrm{C}_{21}, \mathrm{C}_{36}, \mathrm{C}_{58}, \mathrm{C}_{89}\right.$, girls; $\mathrm{C}_{2}, \mathrm{C}_{7}, \mathrm{C}_{35}, \mathrm{C}_{83}$, boys $)$ or shout at them $\left(\mathrm{C}_{16}, \mathrm{C}_{33}, \mathrm{C}_{100}\right.$, girls; $\mathrm{C}_{63}, \mathrm{C}_{85}, \mathrm{C}_{96}, \mathrm{C}_{98}$, boys). One said a female teacher would give them instruction, but with a male teacher they would only watch cartoons $\left(\mathrm{C}_{11}\right.$, girl $)$ and two others said they would not play with a male teacher $\left(\mathrm{C}_{73}\right.$, girl; $\mathrm{C}_{92}$, boy). Five girls said that female children were not allowed to have male teachers, and one boy noted that he had never seen a male preschool teacher in real life $\left(\mathrm{C}_{97}\right.$, boy). Other reasons for preferring female teachers included:

[G]irls have longer hair. $\left(\mathrm{C}_{10}, \mathrm{C}_{37}\right.$, girls)

If I had a male teacher, everything would be disastrous. ( $\mathrm{C}_{13}$, girl $)$

Men ... can't enter a preschool classroom. ( $\mathrm{C}_{39}$, girl $)$

I don't like men. $\left(\mathrm{C}_{78}\right.$, girl $)$

Of the remaining 48 participants who did not express a preference for a female teacher, nearly all $(n=44)$ stated that they would prefer a male one. For some, this was because they already had male teachers, or male relatives who were teachers, or an older sibling with a male teacher. Four boys said that since they were male, their teacher had to be male $\left(\mathrm{C}_{31}, \mathrm{C}_{32}, \mathrm{C}_{69}, \mathrm{C}_{94}\right)$. Other comments from this group included:

Older children's teachers are men and we are old now. $\left(\mathrm{C}_{8}\right.$, boy)

I would like bim and obey his rules. $\left(\mathrm{C}_{20}, \mathrm{C}_{59}\right.$, boys $)$

He would know everything. $\left(\mathrm{C}_{22}\right.$, girl $)$

I don't have a father and he could be my father. (C $\mathrm{C}_{86}$, girl)

Two children stated that gender of their teacher did not matter for them.

Regarding the second picture, of children and a female school-bus driver, about half the participants $(\mathrm{n}=48)$ said that there was a woman driving a car or bus. Others saw a grandmother and children who would go on the school bus $(n=11)$, just the bus and children $(n=9)$, just the children ( $\mathrm{n}=9$ ), just the bus ( $\mathrm{n}=7$ ), or just an old lady $(\mathrm{n}=5)$.

Nearly two-thirds of the participants $(n=65)$ said there was nothing different or interesting in the picture. Of the remainder, 27 stated that an old lady as a driver was interesting because drivers or 
bus drivers are always men; women can't drive at all, or crash; driving is too difficult for old ladies; or school buses are too big.

More than two-thirds of the participants $(n=70)$ stated that they would prefer a male school-bus driver because men were better drivers, while only one in six $(n=17)$ wanted a female school-bus driver, in two case because they wanted a driver with long hair and girls had long hair $\left(\mathrm{C}_{10}, \mathrm{C}_{37}\right.$, girls). One other girl $\left(\mathrm{C}_{6}\right)$ expressed a desire to become a school-bus driver, and one $\left(\mathrm{C}_{100}\right)$ said she was afraid of men. Six participants expressed no gender preference about school-bus drivers.

\section{Family Composition}

Three pictures related to family composition: first, a mother and children; second, a father and children; and third, both parents and children. In terms of whom the participants saw in the first picture, two-thirds $(n=65)$ identified children and their mother. For the second picture, almost as many participants $(n=59)$ saw children and their father. In the third picture, most participants saw either a mother, a father and their children $(n=46)$ or a family $(n=42)$.

Interestingly, 12 participants said that the same picture represented a mother, a teacher and children. Only one participant stated that there was anything different or interesting in this picture, and said:

There are missing people in the first and second pictures but in the third picture, the family was completed. $\left(\mathrm{C}_{100}\right.$, girl)

When asked which picture showed a family, 88 participants picked the third picture, commonly citing togetherness and/or sharing as their reason for having done so. One cited the negative ramifications of any family member being missing:

When there is not my father, who will go to work? When there is not my mother, I will miss her. When there is not me, who will play with toys? $\left(\mathrm{C}_{65}\right.$, boy)

Only two participants stated that there was a family in the first picture, and of these, one $\left(\mathrm{C}_{23}\right.$, girl $)$ said that family meant the mother. Just one participant $\left(\mathrm{C}_{81}\right.$, boy) thought that the second picture showed a family, based on his definition of family as playing with the father. All participants, including two who noted that they had no fathers, emphasized that they wanted their own families to be like the third picture. 


\section{CONCLUSION and DISCUSSION}

Approximately half the participants recognized children in the research tool as being from different races. Three out of four participants stated that they would prefer to play with white children, and about half that they did not want to look like black children. However, only one child who participated in this study had met a person from a different race. Therefore, it seems likely that these prejudices were formed via open or hidden messages in their home environments and/or the media (see Derman-Sparks and A.B.C. Task Force, 1989). As Kustatscher (2017) pointed out, young children absorb the concepts of social class, identity and values like passive sponges, and it is therefore important for adults to consider this whenever spending time with children.

More than half the participants said that a grandmother riding a bike was unusual due to her age, and that they would prefer their grandmothers to knit rather than ride. This rigidity regarding ageappropriate behavior may be culturally based. For instance, Bölükbaş and Arslan's (2003) study of a Turkish retirement home found that the inhabitants did hardly any physical activity, and $91.7 \%$ watched TV all day. The current study's participants' prejudices could have been influenced by personal or media-based knowledge of such environments and role models.

Approximately half the participants mentioned that the disabled people pictured in the protocol were unusual and that they would not prefer to be with them, generally emphasizing the fun activities that such people would not be able to engage in. This parallels the findings of Arslan and Şeker (2011) regarding Turkish society's negative perceptions and prejudices toward individuals with special needs, which may be passed from parents to children.

Roughly two-thirds of the participants did not focus directly on the pictured overweight children's physical characteristics, instead stating that they preferred to play with thin children for various reasons. This echoes some prior studies, such as Penny's (2007) finding that children liked overweight children less than white or black children of average weight, and that children aged up to eight had negative views of the athletic, academic, artistic and social skills of overweight children (see also Altun, 2015; Penny \& Haddock, 2007; Yaran, 1996). Given how closely the children who participated in the current study associated fatness and thinness with beauty and ugliness, it seems probable that culturally imposed beauty criteria were at work in the development of their prejudices in this area.

In the sphere of economic class, the results were much less clear-cut, though most of the participants did say they wanted to play with the "rich" child in the picture because of his new toys 
and clean clothes. Here, it should be borne in mind that social context has a stronger effect on prejudice with increasing age (Raabe \& Beelmann, 2011).

Half the participants found a male preschool teacher and a female school-bus driver unusual, and most said they would prefer the opposite. This may relate to the fact the sample's actual teachers were overwhelmingly female, since Sak et al. (2015) found that children tend to express a general preference for teachers of whichever gender their current teacher is. Some of the current study's participants' beliefs that male teachers were more discipline-oriented and punitive also parallel findings by Sak et al. (2015). This prejudice was probably derived from the children's own experiences, since parents of children with male teachers attach little importance to teachers' gender (Akman et al., 2014; Diamond \& Cooper, 2000). In the case of the female bus driver, the participants' view that driving a motor vehicle was a hard work better done by men than women was probably an echo of occupational gender prejudice in the wider society. For instance, Vannicopulou (2004) examination of children's books found that women were mostly depicted as doing housework and caring for children, while men were depicted as heroes (see also Anlak, 2004).

The participants' universal preference for a classical family consisting of two parents and children may reflect that only eight of them had divorced parents, which in turn might relate to the cultural conservatism of the region of Turkey where the study was conducted.

Lastly, it was found that some of the children's prejudices were nested and interrelated. Bergh and Akrami (2016) reported that it was thought that prejudice was directed toward specific different kinds of target groups but actually all target-specific prejudices were strongly associated and shared a generalized prejudice. In other words, each individual has a sensitivity of us versus them and it is thought that these prejudices are interconnected (Meeusen, Boonen \& Dassonneville, 2017). It is parallel with the finding of the study.

In conclusion, it is noteworthy that the participant children had developed prejudices against a range of people and situations that they had never actually encountered, and that several of their prejudices related to multiple characteristics, e.g., race and appearance; weight, appearance, and athletic ability; age and gender; gender and driving ability; disability and athletic ability; poverty and misbehavior. Based on the findings of this study, preschool teachers should take more account of young children's prejudices and conduct more activities aimed at developing their respect for diversity. Firstly, teachers should be role models and incorporate respect for diversity into their daily routines. Parents should likewise try to evaluate their own prejudices objectively and be better 
role models for their children. And the MoNE should facilitate teachers', parents', and school administrators' planning of multiple activities that connect the goal of respect for diversity with all developmental domains, and not just social-emotional or cognitive skills.

Future studies could usefully use the protocol developed as part of the current study to compare the prejudices of children from different age groups or different regions. The results of such studies could then be used as the basis for a program aimed at improving children's respect for diversity.

\section{REFERENCES}

Akbalık, F. G. (1998). İlkokul öğrencilerinin mesleklerin cinsiyet tipine ilişkin kalıp yargıları [Primary school students' gender stereotyping of occupations]. Ankara Üniversitesi Eğitim Bilimleri Fakültesi Dergisi [Ankara University Journal of Faculty of Educational Sciences], 31(1), 183192.

Akın, A. (2007). Toplumsal cinsiyet (gender) ayırımcıllğı ve sağllk [Gender discrimination and health]. Toplum Hekimliği Bülteni [Bulletin of Community Medicine], 26(2), 1-9.

Akman, B., Taşkın, N., Ozden, Z., \& Okyay, O. (2014). Parents' views on the appointment of male teachers in Turkish preschools. Education as Change, 18(1), 21-32.

Altun, S. (2015). Üniversite ögrencilerinin obęiteye iliskin önyargzlarmm belirlenmesi [Determination of university students' bias against obesity]. Unpublished master's thesis, Başkent University, Turkey.

Anlıak, Ş. (2004). Okul öncesi dönemde çocuğun yaşamında baba ve erkek öğretmenin rolü ve önemi [The importance of father and male teacher in child's life in the period of preschool]. Ege Eğitim Dergisi [Ege Journal of Education], 5, 25-33.

Arslan, S.., \& Kutsal, G. (2001). Yaşlllarda özürlülï̈ü̈n değerlendirmesine yönelik çok merkezli çalısma raporu [Multicenter study report for evaluation of disability in old ages]. Ankara: Başbakanlık Özürlüler Dairesi Başkanlığı ve Türk Tabipler Birliği Yayını.

Aslan, M., \& Şeker, S. (2011). Engellilere yönelik toplumsal algı ve dışlanmışlı:: Sïrt örneği [Social perception and exclusion towards disability: The case of Siirt]. Paper presented at the III. International Symposium on Social Rights, Kocaeli, October 24-25.

Aydilek Çiftçi, M., \& Özgün, Ö. (2011). Okul öncesi dönemdeki çocukların oyuncak tercihlerinin ve akran etkileşimlerinin ebeveyn cinsiyet rolleri alg1sı bağlamında incelenmesi [Peer interactions and toy preferences of preschool aged children as functions of their parents]. e-Journal of New World Sciences Academy, 6(3), 2246-2261.

Aytaç, S., \& Öngen, B. (2013). Üniversite öğrencilerinin toplumsal cinsiyet rollerine ilişkin tutumları ve yaşam değerleri ilişkisi [Attitudes of university students regarding to gender roles and relationship with life values]. Sosyoloji Konferanslar Dergisi [Istanbul Journal of Sociological Studies], $48,1-18$. 
Bağçeli Kahraman, P., \& Başal, H. (2011). Anne eğitim düzeyine göre çocukların cinsiyet kalıpyargiları ile oyun ve oyuncak tercihleri [Play and toys played by children according to mother's educational level with sex role stereotypes]. e-Journal of New World Sciences Academy, 6(1), 1335-1357.

Bergh, R. and Akrami, N. (2016). Generalized prejudice: Old wisdom and new perspectives In: Sibley, C. G. and Barlow, F. K. (Eds.). In Cambridge handbook of the psychology of prejudice (pp. 438-460). Cambridge: Cambridge University Press

Bernard, H. R., \& Ryan, G. W. (2010). Analyzing qualitative data: Systematic approaches. Thousand Oaks, Calif: Sage Publications

Bölükbaş, N., \& Arslan H. (2003). Huzur evinde kalan yaşlların psikososyal yönlerinin incelenmesi [Examination of psychosocial aspects of old people staying in rest home]. Düsünen Adam: Psikiyatri ve Nörolojik. Bilimler Dergisi [The Journal of Psychiatry and Neurological Sciences], 16, 235239.

Creswell, J. W. (2007). Qualitative inquiry and research design: Choosing among five approaches. Thousand Oaks, Calif: Sage Publications.

Creswell, J. W., \& Miller, D. W. (2000). Determining validity in qualitative inquiry. Theory into Practice, 39(3), 124-130.

Çetin, İ. (2012). Önyargzlarmmz nasıl olusur? [How are our prejudices formed?]. Accessed 19 September 2015. http://www.tavsiyeediyorum.com/makale 8149.htm.

Derman-Sparks, L., \& A.B.C Task Force. (1989). Anti-bias curriculum: Tools for empowering young children. Washington: National Association for the Education of Young Children.

Derman-Sparks, L., \& Edwards, J. O. (2010). Anti-bias education for young children and ourselves. Washington, DC: National Association for the Education of Young Children.

Diamond, K. E., \& Cooper, D. G. (2000). Children's perspectives on the roles of teachers and therapists in inclusive early childhood programs. Early Education and Development, 11(2), 203216.

Doyle, A. B., \& Aboud, E. E. (1995). A longitudinal study of white children's racial prejudice as a social-cognitive development. Merrill-Palmer Quarterly, 41, 209-228.

Ekmişoğlu, M. (2007). Erken çocukluk döneminde farklulıklara sayg kavramı bakkında ögretmen görüslerinin incelenmesi ve farklillklara sayg ölçeğinin geçerlik ve güvenirlik callsması (Examining teachers' views about respect for diversities at early childhood period and study of validity and reliability of the scale of respect for diversities]. Unpublished master's thesis, Çanakkale Onsekiz Mart University, Turkey.

Ersoy, E. (2009). Cinsiyet kültürü içerisinde kadın ve erkek kimliği (Malatya örneği) [Woman and man identity in gender culture (Example of Malatya)]. Furat Üniversitesi Sosyal Bilimler Dergisi [Frrat University Journal of Social Science], 19(2), 209-230.

İnci-Kuzu, Ç. (2015). Okul öncesi dönemdeki çocukların cinsiyet önyargıları ile oyuncak seçimi ve ebeveynlerin buna etkisi [The gender prejudice and the toy choice of the children in 
preschool period and the effect of the parents on this]. Uluslararasi Sosyal Arastrmalar Dergisi [The Journal of International Social Research], 8(39), 651-654.

Jackson, S., Joshi, A., \& Erhardt, N. (2003). Recent research on team and organizational diversity: SWOT analysis and implications. Journal of Management, 29(6), 801-830.

Karagöz, E. (2014). Çocuklarda şişmanlık ayrmmolĭğ [Obesity discrimination in cbildren]. Accessed 15 November $2015 \quad$ http://www.sagliktanabiz.com/haberler/cocuklarda-sismanlikayrimciligi-2.html

Karataş, K. (2002). Engellilerin toplumla bütünleşme sorunları: Bir sosyal politika yaklaşımı. Ufkun Ötesi Bilim Dergisi [Beyond the Horizon of Scientific Journal], 2(2), 43-55.

Kowalski, K. (2003). The emergence of ethnic and racial attitudes in preschool-aged children. The Journal of Social Psychology, 143(6), 677-690.

Kustatscher, M. (2017). Young children's social class identities in everyday life at primary school: The importance of naming and challenging complex inequalities. Childhood, 24(3) 381-395. Doi: $10.1177 / 0907568216684540$

Meeusen, C., Boonen, J., \& Dassonneville, R. (2017). The structure of prejudice and its relation to party preferences in Belgium: Flanders and Wallonia compared. Psychologica Belgica, 57(3), 52-74. DOI: http://doi.org/10.5334/pb.335

Merriam, S. B. (2009). Qualitative research: A guide to design and implementation. CA: Jossey-Bass.

MoNE. (2013). Okul öncesi eğitim programı [Preschool program]. Ankara: MEB

Morgan, C. T. (2013). Psikolojizye giriş [Introduction to psychology]. Konya: Eğitim Yayınevi.

Özdemir, E. (2006). Okulöncesi dönem cocuklarmın cinsiyet özelliklerine iliskin kahp yarglarmmn incelenmesi The analysis of sexual stereotypes of preschool children]. Unpublished master's thesis, Ankara University, Ankara.

Penny, H. (2007). Anti-fat attitudes among children. Unpublished doctoral dissertation, Cardiff University, England.

Penny, H., \& Haddock, G. (2007). Anti-fat prejudice among children: The "mere proximity" effect in 5-10 year olds. Journal of Experimental Social Psychology, 43, 678-683.

Pettigrew, T. F. (1958). Personality and sociocultural factors in intergroup attitudes: a cross-national comparison. The Journal of Conflict Resolution, 2, 29-42. Doi: 10.1177/002200275800200104.

Pica, C. (2008). Children's perceptions of interethnic/interracial friendships in a multiethnic school context. Unpublished doctoral dissertation, Massachusetts University, United States.

Raabe, T., \& Beelmann, A. (2011). Development of ethnic, racial, and national prejudice in childhood and adolescence: A multinational meta-analysis of age differences. Child Development, 82(6), 1715-1737. 
Robson, C. (2015). Bilimsel araștirma yöntemleri: Gerçek dünya arasstırması [Real world research]. (Trans. Eds. S.. Çınkır and N. Demirkasımoğlu). Ankara: Anı yayıncılık.

Sak, R., Kızılkaya, G., Yılmaz, Y., \& Dereli, M. (2015). Çocukların bakış açısıyla erkek ve kadın okul öncesi öğretmenleri [Children's perspective: Male and female preschool teachers]. Sakarya Üniversitesi Eğitim Fakültesi Dergisi [Sakarya University Journal Of Education Faculty], 29, 142 162.

Sigelman, C. K., Sigelman, L., Thomas, D. B., \& Ribich, F. D. (1986). Gender, physical attractiveness, and electability: An experimental investigation of voter biases. Journal of Applied Social Psychology, 16, 229-248.

Sonnenschein, W. (1997). The diversity toolkit: How you can build and benefit from a diverse workforce. Illinois: Contemporary Books.

Sürgevil, O. (2008). Farklılık kavramına ve farkllıkların yönetimine temel oluşturan sosyopsikolojik kuramlar ve yaklaşımlar [The socio-psychological theories and approaches that forms the base of diversity and diversity management], Ballkesir Üniversitesi Sosyal Bilimler Enstitüsü Dergisi [Bahkesir University The Journal of Social Sciences Institute], 11(20), 111-124.

Thorman, A. E. (2002). An Evaluation of the Impact of Anti-Bias Curriculum Practices on Prejudicial Racial Attitudes among Children Attending Head Start. Unpublished doctoral dissertation, Kansas State University, United States.

Ünlü, A. (2012). Baž değişkenlere göre okulöncesi çocuklarmmn cinsiyet rolü davranıslarmm incelenmesi [Investigation of gender role behavior of preschool children by some of the variables]. Unpublished master's thesis, Selçuk University, Turkey.

Vannicopulou, A. (2004). Resimli çocuk kitaplarında kadın karakterler [Female characters in children's picture books]." [Trans. Çiftçi Yeşiltuna]. Ege Eğitim Dergisi [Ege Journal of Education], 5(2), 65-73.

Williams, A. T. (2012). I like me, I like you not? The development of implicit racial attitudes in childhood. Unpublished doctoral dissertation, York University, Canada.

Williams K., \& O'Reilly, C. (1998). The complexity of diversity: A review of forty years of research. In B. Staw \& R. Sutton (Eds.), Research in Organizational Behavior (pp. 77-140). Greenwich, CT: JAI Press.

Wolpert, E. (2002). Redefining the norm: Early childhood anti-bias strategies. In E. Lee, D. Menkart \& M. Okazawa-Rey (Eds), Beyond heroes and holidays: A practical guide to K-12 antiracist, multicultural education and staff development (pp. 1-26). Washington, DC: Teaching of Change.

Yağan-Güder, S., \& Güler-Yıldız, T. (2016). Okul öncesi dönemdeki çocukların toplumsal cinsiyet algilarında ailenin rolü [Role of the family in preschool children's perception of gender]. Hacettepe Üniversitesi Ë̈itim Fakültesi Dergisi [Hacettepe University Journal of Education], 31(2), 424-446.

Yaran, I. N. (1996). Stereotypes about obesity. Unpublished mater's thesis, Middle East Technical University, Turkey. 
Zargarpour, S. (2001). Individual differences in children's group perceptions and peer preferences as a function of prejudice level. Unpublished doctoral dissertation, Concordia University, Canada.

Zick, A., Wolf, C., Küpper, B., Davidov, E., Schmidt, P., \& Heitmeyer, W. (2008). The syndrome of group focused enmity: The interrelation of prejudices tested with multiple cross sectional and panel data. Journal of Social Issues, 64, 363-383. Doi: 10.1111/j.1540-4560.2008 .00566.x 